\title{
Authentic Assessment Applied in Authentic English Language Teaching (ELT) Textbook of Vocational School
}

\author{
Puji Sumarsono \\ University of Muhammadiyah Malang \\ pujisumarsono@gmail.com
}

\begin{abstract}
Textbook plays important roles in teaching learning process so that education goals could be achieved. In fact, there have been a lot of vocational schools that cannot provide reliable textbooks, which are research-based and appropriate to students' needs as well as industry's needs. This is one of the factors that the graduates of vocational school could not communicate well, and many of them are jobless especially for jobs that require English skill. Therefore, the textbook which is related to the department in vocational school is really needed. However, there has been a book that covers this needs. This research aims to find whether the book has already provided an authentic assessment as a tool to assess the students' real competence or not. The research method applied was descriptive. Meanwhile, the instrument used was document analysis. The results indicated that the book applies an authentic assessment for three skills: reading, writing, and speaking. However, among the three skills, reading is the activity which is rarely assessed using authentic assessment.
\end{abstract}

Keywords: authentic assessment, textbook, vocational school, automation, and management office

\section{INTRODUCTION}

In the current global marketplace, employers require employees to have a communication skill both written and oral. In fact, available academic exercises which comprise written and oral communication mostly cover academic exercises [1], and neglect the needs of students and industries. Unfortunately, it is believed that teaching and learning English will be meaningful if the materials taught are based on the students' needs. For vocational school students, it should also be based on the needs of business and industrial world (DUDI). In fact, Sumarsono et al. [2] state that available ELT textbooks are criticized by a lot of experts in curriculum and teaching materials [3], [4]. The critics cover two major points: the typical ELT textbooks are designed according to the author's perception, not a research-based or learners' needs, and the textbooks are lack of authenticity. It means that ELT textbook for vocational school needs arranging based on the needs of students and industries. The materials, therefore, need to be authentic.

Authentic is usually defined as having something to do with the real world [5]. According to Wallace in [6], authentic teaching materials are texts that correspond to the reality of life written not for learning purposes.

In addition, Sumarsono et al. [2] explain that authentic English teaching materials are English textwhether academic text of research, such as books and journals, or non-academic text, such as magazines, advertisements, announcements, labels in food wrappers - which are usually read by people whose first language is English.

One of available ELT textbooks of vocational school is English for Automation and Office Management (Authentic Task-Based Materials). It is a book which is written to fulfill students' need to learn English for specific purposes. It is designed according to the syllabus of major of Automation and Office Management. It consists of 10 (ten) chapters. Each chapter presents a reading text, vocabulary list in context, writing, and speaking exercises. The uniqueness of this book is that all materials are authentic, which are created for daily life needs especially for native speakers. In other words, the materials are not intentionally created for teaching and learning English. To understand about advertisement, the book provides the real example of advertisement taken from the mass media. In addition to authentic materials, the topics which are discussed are taken from the 2013 curriculum of Major of Automation and Office Management so that it is closely related to students and curriculum's needs.

The authenticity of a book is not only evaluated based on the authenticity of materials, but also the tasks, exercises or the forms of assessment. Authentic assessment as defined by Mueller [7] is "a form of assessment in which students are asked to perform realworld tasks that demonstrate meaningful application of essential knowledge and skills." Kinay \& Bagceci [8] conducted research on the effects of authentic assessment approach on prospective teachers' problem-solving skills. They concluded that authentic assessment gives positive contribution to the perception of prospective teachers' problem-solving skills; it is recommended to use this 
approach to acquire problem solving skills in teacher education.

This research, therefore, describes authenticity of the assessment presented in the book of English for Automation and Office Management (Authentic TaskBased Materials) using the following descriptions of authentic assessment proposed by Mueller [9].

Traditional - Authentic

Selecting a Response ---------------- Performing a Task

Contrived - Real-life

Recall/Recognition ---------- Construction/Application

Teacher-structured Student-structured

Indirect Evidence - Direct Evidence

\section{RESEARCH METHOD}

The method used in this research was qualitative. The instrument used was documents analysis. The document which was analyzed was Authentic English Language Teaching (ELT) Textbook of Vocational School, the tittle of the book is English for Automation and Office Management (Authentic Task-Based Materials).

\section{RESULTS AND DISCUSSION}

Based on the document analysis, it found that authentic assessments are applied in English for Automation and Office Management (Authentic TaskBased Materials). The assessments are reflected in the tasks presented in the book. They are presented into different three skills (reading task, writing task, and speaking task) in Table 1, Table 2, and Table 3.

Table 1. Authentic Assessment in Reading Task

\begin{tabular}{|c|c|c|}
\hline $\begin{array}{c}\text { Chapter/ } \\
\text { Topic }\end{array}$ & Reading Task & $\begin{array}{c}\text { Authentic } \\
\text { Assessment }\end{array}$ \\
\hline $\begin{array}{l}\text { I/ Press } \\
\text { Release }\end{array}$ & $\begin{array}{l}\text { Students are asked to find } \\
\text { synonym of a word in a text and } \\
\text { answer questions, which the } \\
\text { answers are already stated in text. }\end{array}$ & $\begin{array}{l}\text { No authentic } \\
\text { assessment: } \\
\text { 1. Selecting } \\
\text { response }\end{array}$ \\
\hline $\begin{array}{l}\text { II/ } \\
\text { Advertise } \\
\text { ment/ } \\
\text { Announc } \\
\text { ement }\end{array}$ & $\begin{array}{l}\text { Asking students to analyze, } \\
\text { synthesize, and create new } \\
\text { meaning in the process as well. }\end{array}$ & $\begin{array}{l}\text { Construction/ } \\
\text { Application } \\
\text { of Knowledge }\end{array}$ \\
\hline $\begin{array}{l}\text { III/ } \\
\text { Business } \\
\text { Letter }\end{array}$ & $\begin{array}{l}\text { Asking the questions, which the } \\
\text { answers are already available in } \\
\text { text. }\end{array}$ & $\begin{array}{l}\text { No authentic } \\
\text { assessment: } \\
\text { 1. Recall/Recog } \\
\text { nition of } \\
\text { knowledge } \\
\text { 2. Teacher- } \\
\text { structured }\end{array}$ \\
\hline $\begin{array}{l}\text { IV/ } \\
\text { Personal } \\
\text { Letter }\end{array}$ & $\begin{array}{l}\text { Students are asked to answer true- } \\
\text { false statements and find the } \\
\text { synonym. }\end{array}$ & $\begin{array}{l}\text { No authentic } \\
\text { assessment: } \\
\text { 1. Selecting } \\
\text { response }\end{array}$ \\
\hline $\begin{array}{c}\text { V/ Job } \\
\text { Vacancy }\end{array}$ & $\begin{array}{l}\text { Students are asked to find } \\
\text { synonym of a word in a text and } \\
\text { answer questions, which the } \\
\text { answers are already stated in text. }\end{array}$ & $\begin{array}{l}\text { No authentic } \\
\text { assessment: } \\
\text { 1. Selecting } \\
\text { response }\end{array}$ \\
\hline $\begin{array}{c}\text { VI/ } \\
\text { Proposal }\end{array}$ & $\begin{array}{l}\text { 1. Students are asked to find } \\
\text { synonym. } \\
\text { 2. Asking students to analyze, } \\
\text { synthesize, and create new } \\
\text { meaning in the process as well. }\end{array}$ & $\begin{array}{l}\text { 1. No authentic } \\
\text { assessment } \\
\text { (selecting } \\
\text { response) } \\
\text { 2. Authentic } \\
\text { assessment } \\
\text { (Construction/ } \\
\text { Application of } \\
\text { Knowledge) }\end{array}$ \\
\hline
\end{tabular}

\begin{tabular}{|c|c|c|}
\hline $\begin{array}{c}\text { VII/ } \\
\text { Report }\end{array}$ & $\begin{array}{l}\text { Students are asked to answer true- } \\
\text { false statements and match some } \\
\text { facts. }\end{array}$ & $\begin{array}{l}\text { No authentic } \\
\text { assessment: } \\
\text { Selecting } \\
\text { response }\end{array}$ \\
\hline $\begin{array}{l}\text { VIII/ } \\
\text { Employm } \\
\text { ent } \\
\text { Agreeme } \\
\text { nt }\end{array}$ & $\begin{array}{l}\text { Students are asked to answer true- } \\
\text { false statements and arrange the } \\
\text { jumbled letter. }\end{array}$ & $\begin{array}{l}\text { No authentic } \\
\text { assessment: } \\
\text { Selecting } \\
\text { response }\end{array}$ \\
\hline $\begin{array}{l}\text { IX/ } \\
\text { Company } \\
\text { Profile }\end{array}$ & $\begin{array}{l}\text { Students are asked to answer the } \\
\text { questions, which the answers are } \\
\text { already available in text, and } \\
\text { answer true-false statements. }\end{array}$ & $\begin{array}{l}\text { No authentic } \\
\text { assessment: } \\
\text { Selecting } \\
\text { response }\end{array}$ \\
\hline $\mathrm{X} / \mathrm{MoU}$ & $\begin{array}{l}\text { Students are asked to answer the } \\
\text { questions, which the answers are } \\
\text { already available in text, and } \\
\text { answer true-false statements. }\end{array}$ & $\begin{array}{l}\text { No authentic } \\
\text { assessment: } \\
\text { Selecting } \\
\text { response }\end{array}$ \\
\hline
\end{tabular}

Table 2. Authentic Assessment in Writing Task

\begin{tabular}{|c|c|c|}
\hline $\begin{array}{l}\text { Chapter/ } \\
\text { Topic }\end{array}$ & Writing Task & $\begin{array}{l}\text { Authentic } \\
\text { Assessment }\end{array}$ \\
\hline $\begin{array}{l}\text { I/ Press } \\
\text { Release }\end{array}$ & $\begin{array}{l}\text { Asking the students to write } \\
\text { a press release about the } \\
\text { Minister of Manpower and } \\
\text { Transmigration of Republic } \\
\text { of Indonesia who has just } \\
\text { visited their institution to } \\
\text { inaugurate a training } \\
\text { building for workers. }\end{array}$ & $\begin{array}{l}\text { Performing a } \\
\text { Task }\end{array}$ \\
\hline $\begin{array}{l}\text { II/ } \\
\text { Advertisement/ } \\
\text { Announcement }\end{array}$ & $\begin{array}{l}\text { Students are asked to write } \\
\text { an enticing advertisement } \\
\text { and job vacancy ads. }\end{array}$ & $\begin{array}{l}\text { 1. Performing a } \\
\text { Task } \\
\text { 2. Student- } \\
\text { structured }\end{array}$ \\
\hline $\begin{array}{l}\text { III/ Business } \\
\text { Letter }\end{array}$ & $\begin{array}{l}\text { Students are asked to } \\
\text { complete a letter and write } \\
\text { an order letter. }\end{array}$ & $\begin{array}{l}\text { Performing a } \\
\text { Task }\end{array}$ \\
\hline $\begin{array}{l}\text { IV/ Personal } \\
\text { Letter }\end{array}$ & $\begin{array}{l}\text { Students are asked to write a } \\
\text { personal letter. }\end{array}$ & $\begin{array}{l}\text { Performing a } \\
\text { Task }\end{array}$ \\
\hline $\begin{array}{l}\text { V/ Writing } \\
\text { Application } \\
\text { letter \& CV }\end{array}$ & $\begin{array}{l}\text { 1. Students are asked to put } \\
\text { the phrases in the box into } \\
\text { parts of application letters. } \\
\text { 2. Students are asked to write } \\
\text { application letter. }\end{array}$ & $\begin{array}{l}\text { 1. No authentic } \\
\text { assessment } \\
\text { (Recall/Recog } \\
\text { nition \& } \\
\text { Teacher- } \\
\text { structured) } \\
\text { 2. Authentic } \\
\text { assessment } \\
\text { (Performing } \\
\text { a task) }\end{array}$ \\
\hline $\begin{array}{l}\text { VI/ Writing } \\
\text { Proposal }\end{array}$ & $\begin{array}{l}\text { Students are asked to write a } \\
\text { proposal. }\end{array}$ & $\begin{array}{l}\text { 1. Performing a } \\
\text { Task } \\
\text { 2. Student- } \\
\text { structured }\end{array}$ \\
\hline $\begin{array}{l}\text { VII/ Writing a } \\
\text { Report }\end{array}$ & $\begin{array}{l}\text { Students are asked to write } \\
\text { guided and unguided } \\
\text { business report. }\end{array}$ & $\begin{array}{l}\text { 1. Performing a } \\
\text { Task } \\
\text { 2. Student- } \\
\text { structured }\end{array}$ \\
\hline $\begin{array}{l}\text { VIII/ Writing a } \\
\text { letter of } \\
\text { Employment } \\
\text { Agreement }\end{array}$ & $\begin{array}{l}\text { Students are asked to act } \\
\text { like a secretary of a } \\
\text { company that she/he has to } \\
\text { write an employment } \\
\text { agreement letters for } \\
\text { different positions. }\end{array}$ & $\begin{array}{l}\text { 1. Performing a } \\
\text { Task } \\
\text { 2. Student- } \\
\text { structured }\end{array}$ \\
\hline $\begin{array}{l}\text { IX/ Writing } \\
\text { Company } \\
\text { Profile }\end{array}$ & $\begin{array}{l}\text { Students are asked to write } \\
\text { guided and unguided } \\
\text { company report. }\end{array}$ & $\begin{array}{l}\text { 1. Performing a } \\
\text { Task } \\
\text { 2. Student- } \\
\text { structured }\end{array}$ \\
\hline $\begin{array}{l}\text { X/ Writing a } \\
\text { MoU }\end{array}$ & $\begin{array}{l}\text { Students are asked to write a } \\
\text { simple MoU for } \\
\text { collaboration between } \\
\text { Company X and Company } \\
\text { Y. The topic of } \\
\text { collaboration is free. }\end{array}$ & $\begin{array}{l}\text { 1. Performing a } \\
\text { Task } \\
\text { 2. Student- } \\
\text { structured }\end{array}$ \\
\hline
\end{tabular}


Table 3. Authentic Assessment in Speaking Task

\begin{tabular}{|c|c|c|}
\hline $\begin{array}{l}\text { Chapter/ } \\
\text { Topic }\end{array}$ & Speaking Task & $\begin{array}{c}\text { Authentic } \\
\text { Assessment }\end{array}$ \\
\hline $\begin{array}{l}\text { I/ Press } \\
\text { Release }\end{array}$ & $\begin{array}{l}\text { Presenting a role-play about a } \\
\text { successful press conference. } \\
\text { A student has a role as a } \\
\text { spokesperson, two students } \\
\text { as script writers, and seven } \\
\text { students as journalists. }\end{array}$ & $\begin{array}{l}\text { Performing a } \\
\text { task }\end{array}$ \\
\hline $\begin{array}{c}\text { II/ } \\
\text { Advertisemen } \\
\mathrm{t}\end{array}$ & $\begin{array}{l}\text { Students design an } \\
\text { advertisement and present } \\
\text { their advertisement plan to } \\
\text { their clients. In this session, } \\
\text { they have to convince their } \\
\text { clients the best way they can. }\end{array}$ & $\begin{array}{l}\text { 1. Performing a } \\
\text { task } \\
\text { 2. Construction/ } \\
\text { Application } \\
\text { of } \\
\text { Knowledge } \\
\text { 3. Student- } \\
\text { structured } \\
\text { 4. Real life }\end{array}$ \\
\hline $\begin{array}{l}\text { III/ } \\
\text { Telephoning }\end{array}$ & $\begin{array}{l}\text { 1. Students perform the } \\
\text { dialogue based on the } \\
\text { situation given. } \\
\text { 2. Students find a partner and } \\
\text { make a dialogue that consists } \\
\text { of the expressions for formal } \\
\text { and business like. }\end{array}$ & $\begin{array}{l}\text { 1. Performing a } \\
\text { task } \\
\text { 2. Construction/ } \\
\text { Application } \\
\text { of } \\
\text { Knowledge }\end{array}$ \\
\hline $\begin{array}{l}\text { IV/ Asking } \\
\text { for leave of } \\
\text { absence }\end{array}$ & $\begin{array}{l}\text { Students work in pair to } \\
\text { create and practice a dialogue } \\
\text { between an employee and a } \\
\text { boss talking about asking for } \\
\text { leaving and its consequences. }\end{array}$ & $\begin{array}{l}\text { 1. Performing a } \\
\text { task } \\
\text { 2. Construction/ } \\
\text { Application } \\
\text { of } \\
\text { Knowledge } \\
\text { 3. Student- } \\
\text { structured }\end{array}$ \\
\hline $\begin{array}{c}\mathrm{V} / \mathrm{Job} \\
\text { Interview }\end{array}$ & $\begin{array}{l}\text { Students are asked to work in } \\
\text { pairs to perform a role-play. } \\
\text { Each student acts as either an } \\
\text { interviewer or an interviewee } \\
\text { for a job interview. }\end{array}$ & $\begin{array}{l}\text { 1. Performing a } \\
\text { task } \\
\text { 2. Construction/ } \\
\text { Application } \\
\text { of } \\
\text { Knowledge } \\
\text { 3. Student- } \\
\text { structured }\end{array}$ \\
\hline $\begin{array}{l}\text { VI/ } \\
\text { Presenting a } \\
\text { Chart }\end{array}$ & $\begin{array}{l}\text { Students are asked to present } \\
\text { available chart using their } \\
\text { own analysis. }\end{array}$ & $\begin{array}{l}\text { 1. Performing a } \\
\text { Task } \\
\text { 2. Construction/ } \\
\text { Application } \\
\text { 3. Student- } \\
\text { structured } \\
\text { 4. Direct } \\
\text { Evidence }\end{array}$ \\
\hline $\begin{array}{l}\text { VII/ } \\
\text { Delivering a } \\
\text { Report }\end{array}$ & $\begin{array}{l}\text { After finishing business } \\
\text { report writing, students } \\
\text { should perform or deliver it } \\
\text { orally in front of their } \\
\text { manager clearly and give } \\
\text { conclusion of their project. }\end{array}$ & $\begin{array}{l}\text { 1. Performing a } \\
\text { task } \\
\text { 2. Construction/ } \\
\text { Application } \\
\text { of } \\
\text { Knowledge }\end{array}$ \\
\hline $\begin{array}{c}\text { VIII/ } \\
\text { Negotiation }\end{array}$ & $\begin{array}{l}\text { Students are asked to } \\
\text { negotiate with a boss, } \\
\text { partner, and customer. }\end{array}$ & $\begin{array}{l}\text { 1. Performing a } \\
\text { task } \\
\text { 2. Construction } \\
\text { /Application } \\
\text { of } \\
\text { Knowledge }\end{array}$ \\
\hline $\begin{array}{l}\text { IX/ Presenting } \\
\text { Company } \\
\text { Profile }\end{array}$ & $\begin{array}{l}\text { After finishing company } \\
\text { profile writing, students } \\
\text { should present it orally in } \\
\text { front off the class. }\end{array}$ & $\begin{array}{l}\text { 1. Performing a } \\
\text { task } \\
\text { 2. Construction } \\
\text { /Application } \\
\text { of } \\
\text { Knowledge }\end{array}$ \\
\hline $\begin{array}{l}\text { X/ Master of } \\
\text { Ceremony }\end{array}$ & $\begin{array}{l}\text { Students are asked to } \\
\text { perform a role-play as a } \\
\text { master of ceremony for } \\
\text { graduation day at school. }\end{array}$ & $\begin{array}{l}\text { 1. Performing a } \\
\text { task } \\
\text { 2. Construction } \\
\text { /Application } \\
\text { of }\end{array}$ \\
\hline
\end{tabular}

Knowledge

The findings presented above indicate that authentic assessments are applied in the three skills: reading, writing, and speaking. However, among those skills, reading is the skill which rarely applies the authentic assessment. Reading activities are divided into three steps: pre-reading, let's read, and reading task. In prereading, the book presents pre-reading questions which require the students to answer based on their daily experiences. This is in line with the research finding conducted by Alemi \& Ebadi [10]. They stated that presenting prior information through pre-reading activities could be a useful way for teachers to help students comprehend reading text. Let's read presents reading text that students should read. Reading Task is presented after Let's read, which presents activities for students to answer questions

Among ten chapters only one chapter (chapter I) which applies authentic assessment. However, for prereading, all ten chapters apply authentic assessments as the questions ask to the students to answer according to student's real-life, the answers should show direct evidence, and the answer should be student-structured. In writing and speaking tasks, all of the tasks reflect authentic assessments, such as performing task, construction/application of knowledge, and studentsstructured. Role-play is often applied in speaking task.

\section{ACKNOWLEDGMENTS}

The author thanks to Faculty of Teacher Training and Education, University of Muhammadiyah Malang (FTTE UMM) for the financial supports and to Muhammadiyah Vocational High School (SMK) 8 Pakis that provides the data to be analyzed together. However, any opinions, findings, conclusions or recommendations expressed in this material are those of the researcher and do not necessarily reflect the views of the FTTE UMM.

\section{REFERENCES}

[1] T.L., Larkin, The Student Conference: A Model of Authentic Assessment. International Journal of Engineering Pedagogy. Volume 4, Issue 2, 2014.

[2] P. Sumarsono, et al. The Development of Authentic English Language Teaching (ELT) Textbook of Vocational School. International Journal of English Research. Volume 3; Issue 6; Page No. 29-31, 2017

[3] H. Rahman. Authentic Tasks for Vocational EFL Learners in Suburb: Assure Model using ComputerAssisted Audiovisual. Proceedings International Seminar on Language Education and Culture. http://sastra.um.ac.id/wpcontent/uploads/2017/11/62-72-Hairudin-Rahmanedited layouted.doc.pdf, 2017

[4] M. Batsila. Linking Vocational Education to the World of Employment: The Case of Business English in Greece. http://oro.open.ac.uk/49571/7/BATSILA.pdf, 2016

[5] B.B. Frey, V. L. Schmitt \& J. P. Allen Defining Authentic Classroom Assessment. Practical 
Assessment, Research \& Evaluation. Volume 17, Number 2, 2012.

[6] S.A. Berardo. The use of authentic materials in the teaching of reading. The Reading Matrix Vol. 6, No. 2, 2006

[7] J. Mueller, The Authentic Assessment Toolbox: Enhancing Student Learning through Online Faculty Development. Journal of Online Learning and Teaching. Volume 1, Number 1, 2005

[8] I. Kinay \& B. Bağçeci, The Investigation of the Effects of Authentic Assessment Approach on Prospective Teachers' Problem-Solving Skills. International Education Studies; Vol. 9, No. 8, 2016.
[9] J. Mueller, Authentic assessment toolbox. Retrieved from

http://jfmueller.faculty.noctrl.edu/toolbox/whatisit.h tm\#top. 2016

[10] M. Alemi \& S. Ebadi, The Effects of Pre-reading Activities on ESP Reading Comprehension. Journal of Language Teaching and Research, Vol. 1, No. 5, pp. 569-577, 2010, doi:10.4304/jltr.1.5.569-577. 